\title{
SIMILARITY OF PRESENT-DAY VARIATIONS IN METHANE BACKGROUND CONCENTRATIONS IN THE SURFACE LAYER OF THE ATMOSPHERE AT DIFFERENT LATITUDES
}

\author{
S.M. Semenov ${ }^{1,2)}$ \\ 1) Yu. A. Izrael Institute of Global Climate and Ecology, \\ 20B, Glebovskaya str., 107258, Moscow, Russia; SergeySemenov1@yandex.ru \\ 2) Institute of Geography of the Russian Academy of Sciences, \\ 29, Staromonetny lane, 109017, Moscow, Russia
}

Abstract. Variations in methane concentrations in the surface layer are studied using monthly averages provided by the Global Atmospheric Sampling Laboratory (GASLAB), Australia. Flask measurements have been carried out at the network of monitoring stations of the Commonwealth Scientific and Industrial Research Organization (CSIRO). Mainly data of 1991-2014 are analyzed in this paper. On the yearly time scale, the variations are studied using yearly running averages. Differences between bimestrial running averages and yearly running averages are employed for the analysis of variations on the seasonal time scale. On the yearly scale, after the elimination of systematic differences in $\mathrm{CH}_{4}$ levels, trends became similar at all stations. For the stations of the Southern Hemisphere, respective curves differ by several ppb only. The similarity of variations at all stations was found also on the seasonal scale. The oscillations observed have seasonal cyclicality and the stable shape. Strong correlations are found for different stations. However, the correlations are manifested only after respective time shifts accounting for seasonality have been applied. Methane levels are increased in the cold period of year and decreased in the warm period. Such type of variations supports the following hypothesis: $\mathrm{CH}_{4}$ variations on the seasonal time scale are caused by seasonal changes in hydroxyl burden in the lower atmosphere.

Keywords. Present-day variations, global level, concentrations, surface layer, methane, similarity, different latitudes.

\section{СХОДСТВО СОВРЕМЕННЫХ ИЗМЕНЕНИЙ ФОНОВЫХ КОНЦЕНТРАЦИЙ МЕТАНА В ПРИПОВЕРХНОСТНОМ СЛОЕ АТМОСФЕРЫ НА РАЗЛИЧНЫХ ШИРОТАХ}

$$
\text { С.М. Семенов }{ }^{1,2)}
$$

\footnotetext{
1) Институт глобального климата и экологии имени академика Ю.А. Израэля,
} Россия, 107258, Москва, ул. Глебовская, д. 20б; SergeySemenov1@yandex.ru

2) Институт географии РАН,

Россия, 109017, Москва, Старомонетный пер., дом 29

Реферат. Проанализированы изменения концентраций метана в приповерхностном слое по среднемесячным данным Глобальной атмосферной пробоот- 
борной лаборатории (Global Atmospheric Sampling Laboratory, GASLAB), Австралия. Фляжечные измерения проводились на глобальной сети станций Научной и промышленной исследовательской организации Содружества наций (CSIRO). В этой работе использованы данные в основном за 1991-2014 гг. Изменения характеризовались в годовом масштабе времени - годовыми скользящими средними, а в сезонном масштабе времени - двухмесячными скользящими средними, из которых вычтены годовые скользящие средние. В годовом масштабе времени, после удаления систематических различий в уровнях $\mathrm{CH}_{4}$, тенденции изменений на всех станциях оказались сходными, причем для станций Южного полушария соответствующие кривые различаются всего на несколько млрд ${ }^{-1}$. В сезонном масштабе времени также обнаружено сходство изменений на всех станциях. Наблюдаемые колебания имеют сезонную цикличность, их форма устойчива. Для разных станций обнаружены сильные корреляционные связи. Однако они проявляются лишь при определенных сдвигах во времени, учитывающих сезонность. Увеличение уровней метана наблюдается в холодный период года, а уменьшение - в теплый. Характер этих изменений совместим с предположением о том, что их причина - сезонные изменения содержания гидроксил-радикалов в нижней атмосфере.

Ключевые слова. Современные изменения, глобальный уровень, концентрации, приповерхностный слой, метан, сходство, разные широты.

\section{Introduction}

Methane is the second of the gases emitted due to economic activity having the major contribution to the greenhouse effect, the first being $\mathrm{CO}_{2}$ (Myhre et al, 2013, p. 677). All the relative indices calculated per given additional emission or per given increase in the atmospheric burden, shows that methane has by one order higher greenhouse efficiency than carbon dioxide. These properties of methane, as well as its expected increased emission and contribution to the greenhouse effect require careful evaluation of its global levels and their drivers.

The objectives of this paper are as follows:

- characterize variations in the background levels of methane concentration in the surface layer of the atmosphere in polar, temperate, and tropical latitudes using the yearly and seasonal time scales;

- detect similarity and differences of those variations, in particular between Northern and Southern Hemispheres.

\section{Data and methods}

Background concentrations of major greenhouse gases in the surface layer of the atmosphere are monitored at the global measurement networks. One of them is the flask measurement network of the Commonwealth Scientific and Industrial Research Organization (CSIRO). It is a sampling network, i.e., certain amounts of air are sampled, stored in special flasks and then analyzed in the Global Atmospheric Sampling Laboratory (GASLAB), Australia. Data and references to publi- 
cations devoted to the methodological aspects of methane measurements (see, e.g., (Francey et al, 2003)) as well as to data analysis can be found at http://cdiac.essdive.1bl.gov/trends/co2/modern_co $2 . h t m l(\rightarrow D A T A, \rightarrow$ CSIRO). D.M. Etheridge, P.B. Krummel, R.L. Langenfelds, L.P. Steele and some other leading CSIRO scientists took part in this long-term research activity. The archive $<$ CSIRO_gaslab data_Jul2015.zip > from the above internet-resource is used in this paper. Monitoring data on concentrations from those and many other stations can also be found at the site of the WMO World Data Centre for Greenhouse Gases (https:// ds.data.jma.go.jp/gmd/wdcgg/cgi-bin/wdcgg/catalogue.cgi ).

The geographical characteristics of CSIRO sampling sites (hereinafter referred as 'stations') are given in Table 1. Data from five stations located in the Northern Hemisphere and six stations located in the Southern Hemisphere are analyzed in this paper. Time spans covered by the series of methane monthly data from these stations are also given in this table.

Table 1. Location of stations of the flask measurement network of CSIRO and time spanning of their monthly series of methane concentrations. Source: http://cdiac.essdive.lbl.gov/trends/co2/modern_co $2 . h t m l(\rightarrow$ DATA,$\rightarrow$ CSIRO $)$

\begin{tabular}{|c|c|c|c|c|c|c|}
\hline $\begin{array}{l}\text { Station } \\
\text { code }\end{array}$ & $\begin{array}{l}\text { Station name } \\
\text { and location }\end{array}$ & $\begin{array}{c}\text { Latitude, } \\
\text { degree }\end{array}$ & $\begin{array}{c}\text { Longitude, } \\
\text { degree }\end{array}$ & $\begin{array}{l}\text { Elevation } \\
\text { (station), } \\
\text { m. a. s. l. }\end{array}$ & $\begin{array}{c}\text { Elevation } \\
\text { (sampling), } \\
\text { m. a. s. l. }\end{array}$ & Time span \\
\hline ALT & Alert, Canada & 82.50 & -62.33 & 200 & 210 & 1991-2014 \\
\hline ESP & $\begin{array}{l}\text { Estevan Point, } \\
\text { Canada }\end{array}$ & 49.38 & -126.53 & 7 & 47 & 1993-2002 \\
\hline SIS & $\begin{array}{l}\text { Shetland Islands, } \\
\text { UK }\end{array}$ & 60.08 & -1.25 & 30 & 33 & $1992-2003$ \\
\hline MLO & Mauna Loa, USA & 19.53 & -155.57 & 3397 & 3435 & $1991-2014$ \\
\hline CRI & Cape Rama, India & 15.08 & 73.83 & 60 & 66 & $\begin{array}{l}1993-2002 \\
2009-2013\end{array}$ \\
\hline CFA & $\begin{array}{l}\text { Cape Ferguson, } \\
\text { Australia }\end{array}$ & -19.28 & 147.05 & 2 & 5 & $1991-2014$ \\
\hline $\mathrm{CGO}$ & $\begin{array}{l}\text { Cape Grim, } \\
\text { Australia }\end{array}$ & -40.68 & 144.69 & 94 & 164 & 1984-2014 \\
\hline CYA & Casey, Antarctica & -66.28 & 110.51 & 47 & 55 & $1997-2014$ \\
\hline MAA & $\begin{array}{l}\text { Mawson, } \\
\text { Antarctica }\end{array}$ & -67.61 & 62.86 & 32 & 42 & 1984-2014 \\
\hline MQA & $\begin{array}{l}\text { Macquarie Island, } \\
\text { Australia }\end{array}$ & -54.48 & 158.96 & 6 & 13 & $1990-2014$ \\
\hline SPO & $\begin{array}{l}\text { South Pole, } \\
\text { Antarctica }\end{array}$ & -89.98 & -24.8 & 2837 & 2847 & 1991-2014 \\
\hline
\end{tabular}

Theoretically, these stations are not influenced by any particular significant sources of methane emissions. i.e., the network is to measure the global background levels of methane ${ }^{1)}$. This means that methane levels at these sites are determined by the global processes of transmission and mixing as well as of natural methane sink. We remind that methane sources are situated on the Earth's surface, while methane destruction takes place mainly in the atmosphere through chemical

1) It is demonstrated below that some stations do not completely fit the criterion. 
reactions with hydroxyl in the troposphere and atomic chlorine in the stratosphere (Cicerone, Oremland, 1988; Karol, Kiselev, 2004; Naik et al., 2013; Vulgarakis et al., 2013; Eliseev, 2018).

We use the monthly averages of methane concentrations from the archive $<$ CSIRO_gaslab data_Jul2015.zip $>$ downloaded from http:/cdiac.ess-dive.lbl.gov/ trends/co2/modern_co2.html $(\rightarrow$ DATA, $\rightarrow$ CSIRO) in March 2018. Time coverage of the data series is rather continuous. The measurements were suspended for many years at the station CRI only. However, even in those years when measurements took place, data for some months are absent. Therefore, for the convenience of algorithmic data processing such gaps were filled using the procedure given in (Semenov, Gelver, 2002). We remind it here in short.

Let us consider two matrixes: $V=\left(v_{i j}\right)$ and $F=\left(f_{i j}\right)$, where $i=1, \ldots, I$ and $j=$ $1, \ldots, J$. Matrix $V$ is a dataset of measurements, while matrix $F$ characterizes the presence or absence of data: $f_{i j}=1$ if datum $v_{i j}$ is available, and $f_{i j}=0$ if this datum is not available. In this study we assume that index $i$ is the sequential number of a year for which some monthly data are available. Index $j$ denotes the sequential number of a month within the calendar year $(J=12)$.

The data are presented in the following form:

$$
v_{i j}=a_{i}+b_{j}+\theta_{i j}
$$

where $a_{1}, \ldots, a_{I}$ and $b_{1}, \ldots, b_{J}$ are unknown parameters, and $\theta_{i j}$ are random deviations (centered random values); $\sum_{j}^{J} b_{j}=0$. Variables $a$ denote annual means, while variables $b$ quantify the centered yearly course of monthly values. The parameters are found using the least-squares method. If the element $v_{i j}$ is absent in the initial dataset, it is replaced with $\left(a_{i}+b_{j}\right)$ in further deliberations.

For each station, three series are derived from its initial series of monthly mean concentrations (see Fig. 1). The series are labeled as $A, B$ and $B-A$ :

$A$ ) the series of yearly running averages, i.e., means for 12 sequential months; the value is associated with 00:00 of the $1^{\text {st }}$ day of the $7^{\text {th }}$ month (the moment between the $6^{\text {th }}$ and $7^{\text {th }}$ months);

$B$ ) the series of bimestrial running averages, i.e., means for the $6^{\text {th }}$ and $7^{\text {th }}$ months; the value is associated with the same moment;

$B-A$ ) the difference between series $B$ and $A$.

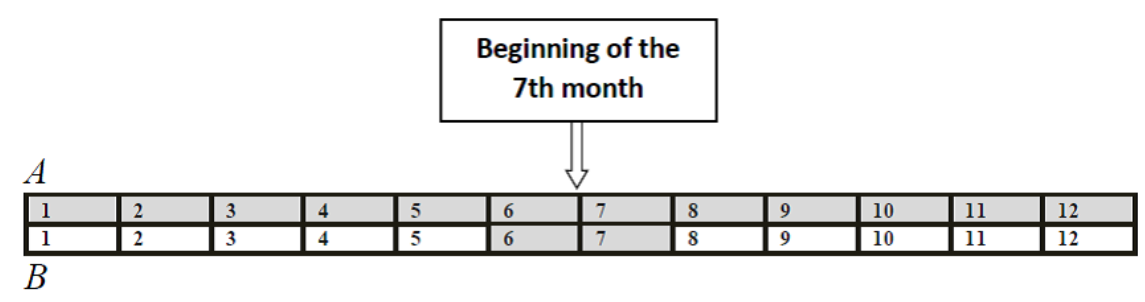

Figure 1. On two scales presented the 'running set' of 12 sequential months, the time spans used for the construction of series $A$ (the upper scale) and $B$ (the lower scale) are shadowed; the results of averaging are associated with the beginning of the $7^{\text {th }}$ month

The length differences between calendar months are not taken into account in the construction of series $A$ and $B$. 
The variability of concentrations on the yearly time scale will be further characterized with series $A$, while seasonal variability will be analyzed using series $B$ - $A$. The series will be labelled as 'series of type $A$ ' and 'series of type $B-A »$, or $A$ series and $B$ - $A$-series in short.

For the decimal representation of moments within a year, i.e., time passed from zero moment, the previous year is shown before the decimal delimiter, e.g., 2017.5 means the middle of year 2018 .

The following terminology is applied in the calculations of cross-correlations of series for different time shifts $\tau$ (months). An ordered pair of series $\{X(t)\}$ and $\{Y(t)\}$ is always considered in the calculations. The first series $\{X(t)\}$ will never be shifted, while a time shift of the second one will be made through addition of $\tau$ to the argument: $\{Y(t+\tau)\}$. If $\tau>0$, the shift will be called a 'backward shift for $\tau$ months', while under $\tau<0$ the shift will be called a 'forward shift for $|\tau|$ months, ${ }^{2)}$. The correlation coefficient is calculated employing the usual formula for the series $\{X(t)\}$ and $\{Z(t)\}$, where $Z(t)=Y(t+\tau)$. Only those moments $t$ are involved, for which the elements of both series are available. The time shift $\tau,-5<\tau<6$, yielding the maximal correlation is called 'the optimal time shift'.

\section{Results and discussion}

For the comparison of variations in methane concentrations on the yearly time $\underline{\text { scale, }}$, the $A$-series (i.e. yearly running averages) for different stations were transformed as follows. For each station (let SSS be a common station code) we considered the subsets of months where $A$-series elements are available for both SSS and ALT stations. Then, the mean concentrations over the subset are calculated for both stations. The difference between these mean values for $\mathrm{ALT}^{3)}$ and SSS. is denoted as $\Delta_{\text {ALT }}$. The results are given in Table 2 .

Table 2. Systematic differences $\Delta_{\mathrm{ALT}}$ in methane concentrations between ALT and other stations, ppb

\begin{tabular}{|c|l|l|l|l|l|l|l|l|l|l|}
\hline $\begin{array}{c}\text { Station } \\
\text { code }\end{array}$ & SIS & ESP & MLO & CRI & CFA & CGO & MQA & CYA & MAA & SPO \\
\hline$\Delta_{\text {ALT }}$ & 8.83 & 13.86 & 69.03 & 31.41 & 124.57 & 129.58 & 129.09 & 128.16 & 129.85 & 129.87 \\
\hline
\end{tabular}

As clear from $\Delta_{\mathrm{ALT}}$ values (see Table 2), background methane levels discernibly vary over the Northern Hemisphere stations and substantially exceed the respective levels at the Southern Hemisphere stations. To adjust for those systematic differences, respective $\Delta_{\text {ALT }}$ was added to the elements of the $A$-series of each station. Thus, systematic differences were eliminated, and just time trends can be considered.

The series obtained through the adjustment for six stations of the Southern Hemisphere are displayed in Fig. $2 a$. It is seen that stations register similar variations in methane concentration. Differences in some curves of the polar stations are hardly detectable in the figure. In general, differences are small, few ppb units.

2) If $\tau>0$, the series $\{Y(t)\}$ is shifted to earlier dates, i.e., against the time flow, while for $\tau<0$ it is shifted to later dates, i.e., along with time.

3) The chosen station ALT is the highest-latitude station of the Northern Hemisphere. 
Therefore, it is expedient to construct an averaged series SH_AV for further comparison with $A$-series of stations of the Northern Hemisphere. Data of 1991-2014 were used in this averaging. The shorter series of station CYA was not involved.

The series for five stations of the Northern Hemisphere and series SH_AV (the black bold line) are displayed in Fig. $2 b$. It is clear that in general the trends in concentrations at those stations on the yearly time scale are similar to those for the Southern Hemisphere. However, some multi-year deviations observed reach 10-20 ppb. The tropical station Cape Rama (CRI, the dark blue line) located in India is an evident outlier. Deviations from the average line for the Southern Hemisphere are more substantial. The further data analysis for this station is problematic, because measurements were suspended for a long time in 2000s. Data on this station are omitted in Fig. $2 c$.
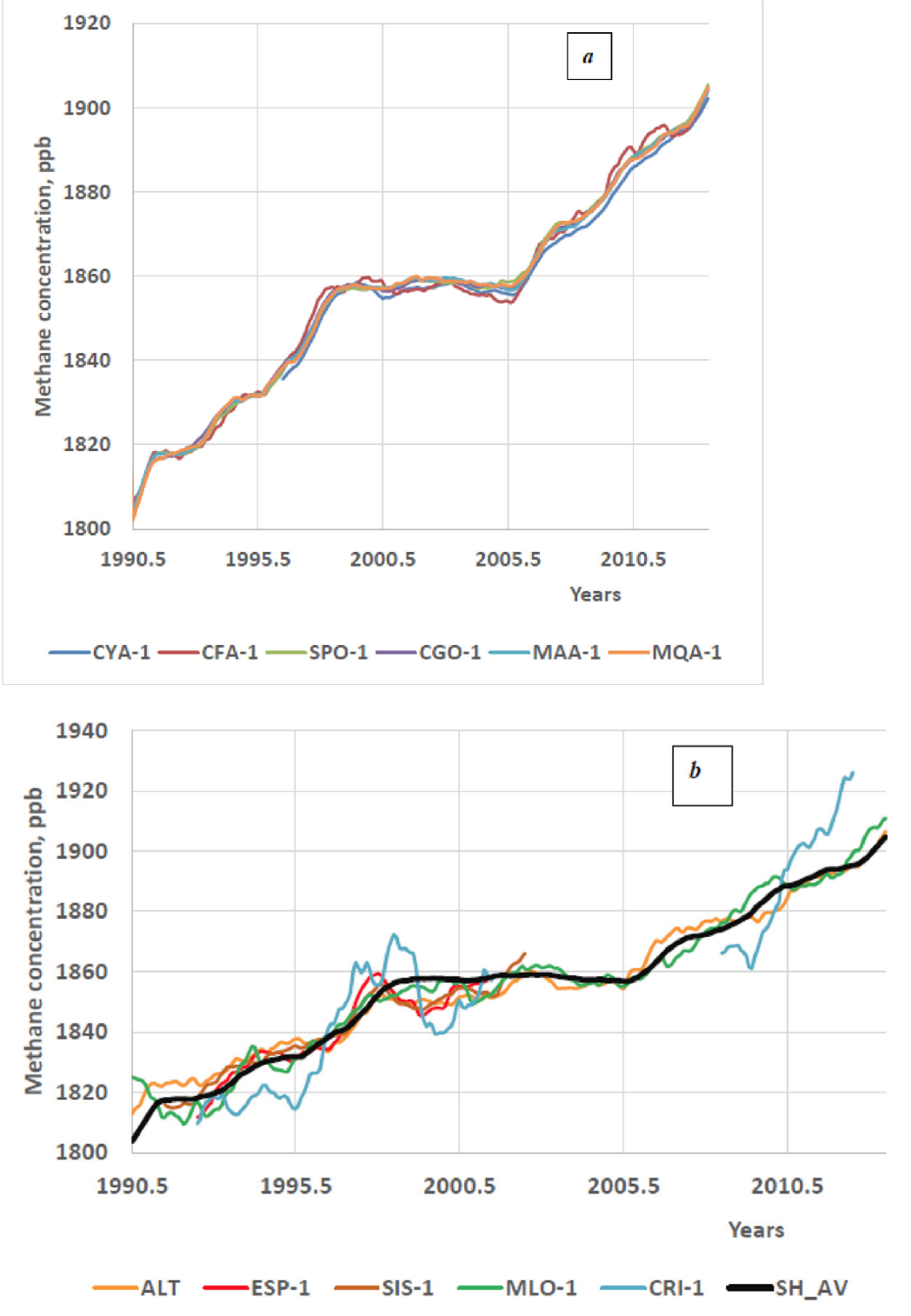


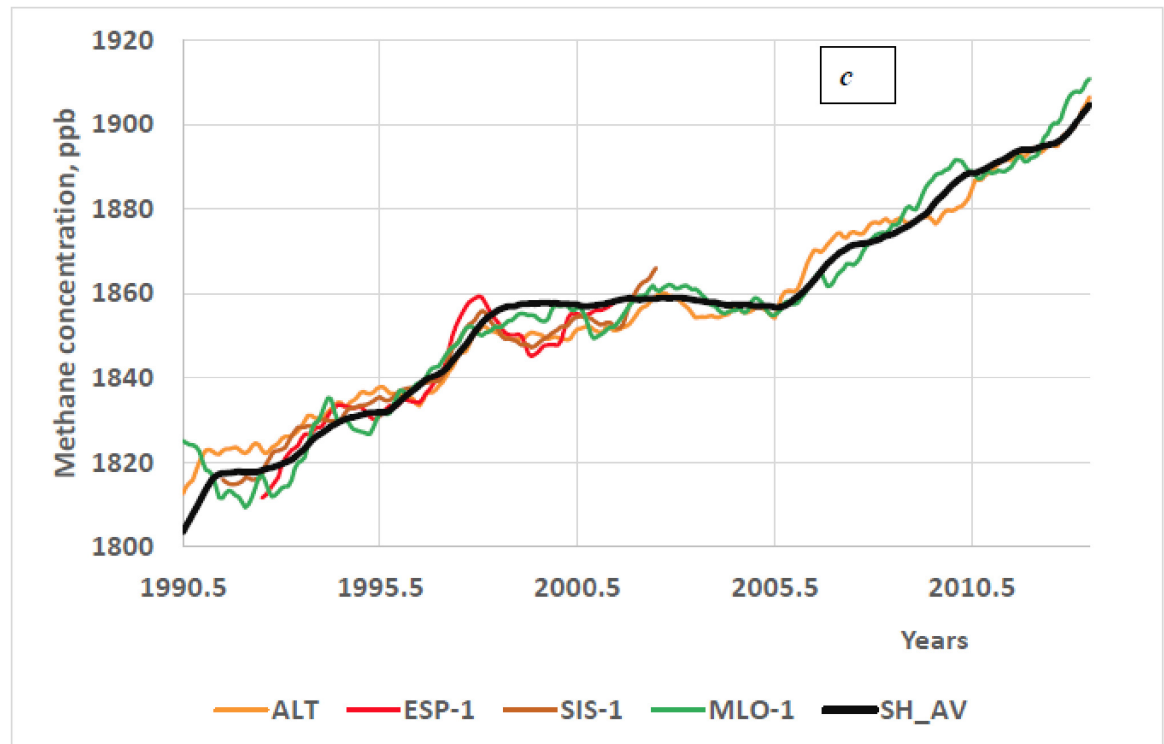

Figure 2. Variations in $\mathrm{CH}_{4}$ concentrations (ppb), yearly running averages; systematic differences in concentrations from station ALT are eliminated that is marked by adding ' 1 ' to the station code in the legend (e.g., 'SPO-1'): $a$ ) the Southern Hemisphere stations; $b$ ) the Northern Hemisphere stations and the average series SH_AV for the Southern Hemisphere; $c$ ) the same as $b$, but station CRI is omitted

$B-A$-series of two stations of the Southern Hemisphere, namely, Mawson (MAA) and Cape Grim (CGO), are shown in Fig. $3 a$. They characterize variability of concentrations on the seasonal time scale. The stations are chosen for the illustration, because methane measurements have been performed there for the longest period, since 1984. The correlation coefficient is estimated at more than 0.99 . The amplitudes are roughly equal. The yearly cyclicality and stable form of the oscillations, with maxima in the cold season of the year and minima in the warm season, should be noted.

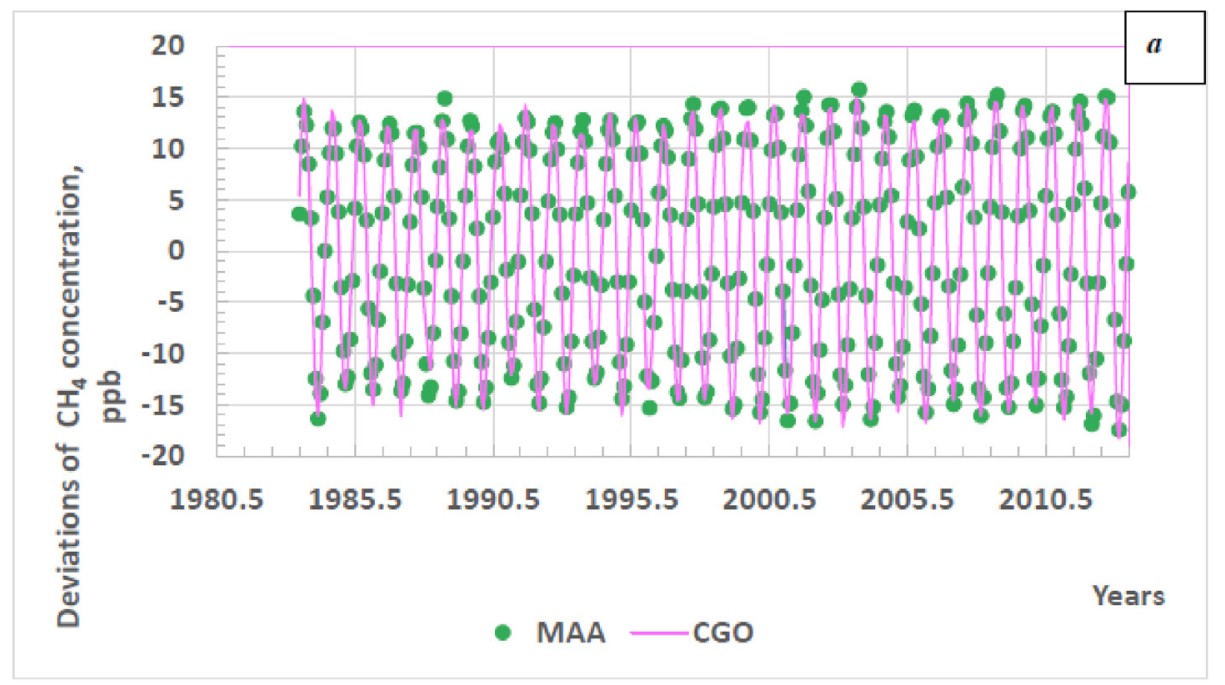




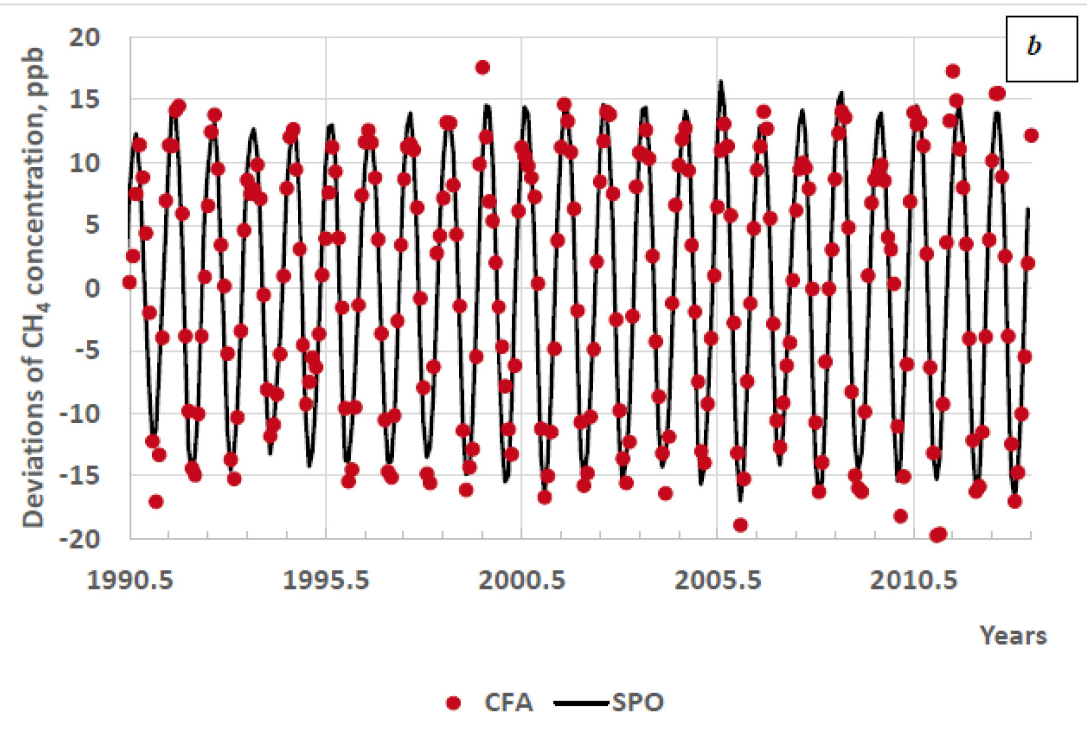

Figure 3. Deviations of methane concentration at the Southern Hemisphere stations, ppb; the seasonal time scale: $a$ ) stations MAA and CGO; the colors differ from those used in Fig. 2 to ensure the image contrast; $b$ ) stations CFA and SPO (the series for SPO is shifted backward in time by 1 month)

High level of similarity of deviations of methane concentration on the seasonal time scale is observed at all stations of the Southern Hemisphere. The correlation coefficients of $B-A$-series for stations MAA, CYA, MQA, CGO and the series for SPO station (the South Pole) are estimated at more than 0.99, and for the tropical (!) station CFA and station SPO, at 0.95 . While the correlation coefficient calculation for the first four stations did not require any time shifts, for station CFA the SPO series was shifted backward in time by 1 month. The $B-A$-series for CFA and SPO are displayed in Fig. $3 b$.

$B-A$-series for high-latitude polar station Alert (ALT, $82.5^{\circ} \mathrm{N}$ ) has also strong correlative similarity with all stations of the Southern Hemisphere. The coefficients of correlation of the series of those stations with the Alert series are as follows: 0.92 for SPO, 0.91 for MAA, 0.91 for CYA, 0.93 for MQA, and 0.89 for CFA. However, such similarity is revealed if the Alert series is shifted backward in time by 5 months. Data for stations ALT and SPO are shown in Fig. 4a, and those for station ALT and tropical station CFA, in Fig. $4 b$.

There are also rather strong correlations between $B-A$-series of the Northern Hemisphere and the series of station ALT: 0.83 for station ESP, 0.84 for station SIS, 0.75 for station MLO, and 0.81 for station CRI. No time shifts are needed except for the tropical station CRI. In this case a backward shift by 1 month is applied to the series for station ALT.

The estimates of correlation coefficients of $B$ - $A$-series for all 11 stations are presented in Table 3. The groups of stations of the Southern Hemisphere and Northern Hemisphere are shown with different colors. It is clear that within-group correlations are high. They are achieved with no time shifts for the stations of 
temperate and polar latitudes. The optimal shift reaches 1 month in tropical latitudes. The correlations of $B-A$-series are also rather strong for the stations of different groups. However, the optimal time shifts may become 5 months. We remind that time shifts are defined for the ordered pairs of stations. In Table 3, a shift is presented for the station series given in the column. For example, the correlation coefficient of $B$ - $A$-series for stations SPO and CFA is 0.95 if the series of station CFA is shifted forward in time by 1 month.
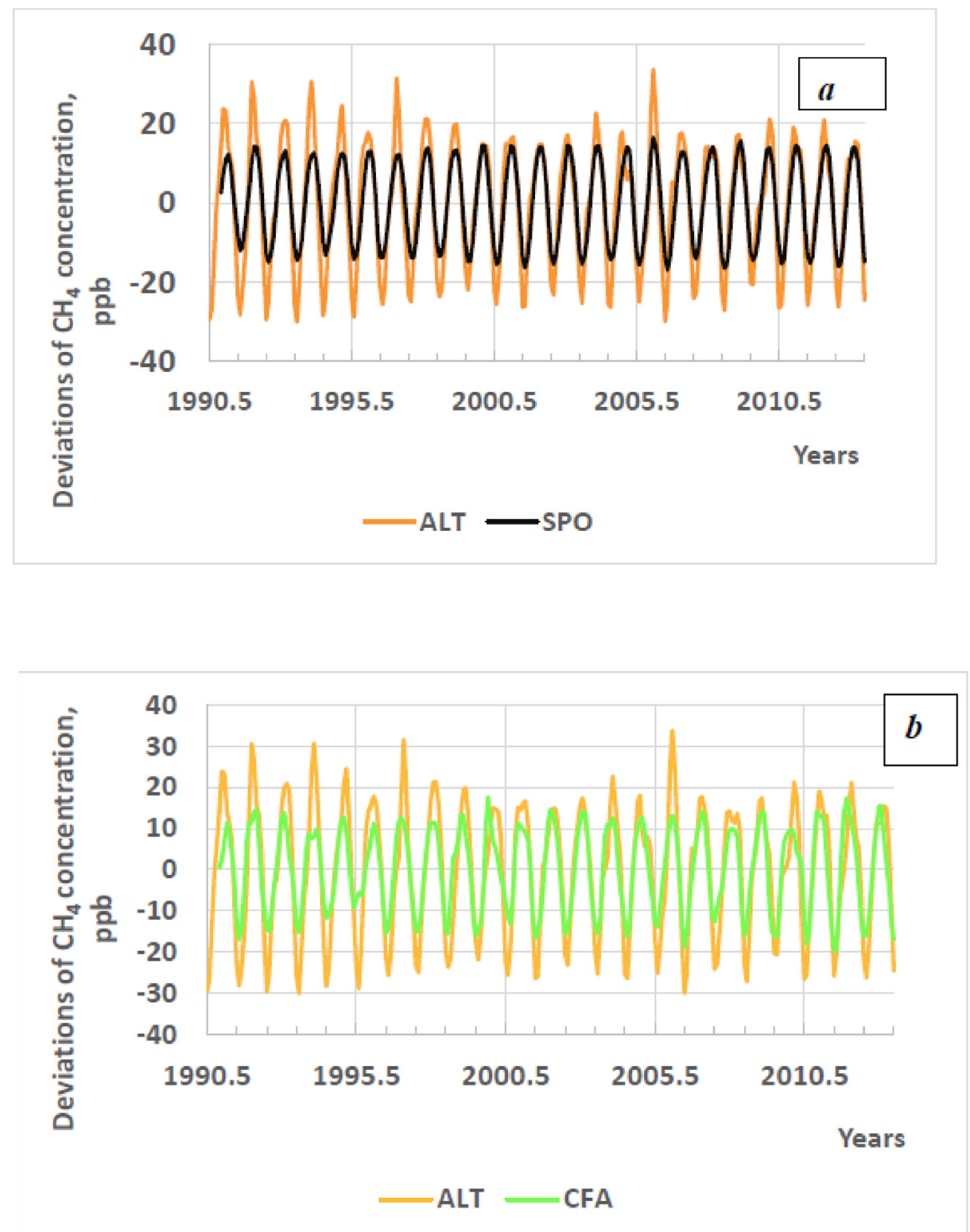

Figure 4. Deviations of methane concentrations, ppb; seasonal time scale: $a$ ) stations SPO and ALT; b) stations CFA and ALT. The series of station ALT is shifted backward in time by 5 months 
Table 3. The estimates of correlation coefficients of $B$ - $A$-series for 11 sampling stations of the CSIRO network.In the ordered pair of stations, the first one is given in the first column and the second one, in the first row.The optimal shift (months) is indicated under the estimate

\begin{tabular}{|c|c|c|c|c|c|c|c|c|c|c|c|}
\hline & SPO & MAA & CYA & MQA & CGO & CFA & CRI & MLO & ESP & SIS & ALT \\
\hline \multirow[t]{2}{*}{ SPO } & 1.00 & 1.00 & 0.99 & 0.99 & 0.99 & 0.95 & 0.88 & 0.74 & 0.79 & 0.80 & 0.92 \\
\hline & 0 & 0 & 0 & 0 & 0 & -1 & 3 & 4 & 5 & 5 & 5 \\
\hline \multirow[t]{2}{*}{ MAA } & 1.00 & 1.00 & 1.00 & 0.99 & 0.99 & 0.96 & 0.88 & 0.73 & 0.80 & 0.82 & 0.91 \\
\hline & 0 & 0 & 0 & 0 & 0 & -1 & 3 & 4 & 5 & 5 & 5 \\
\hline \multirow[t]{2}{*}{ CYA } & 0.99 & 1.00 & 1.00 & 0.98 & 0.99 & 0.96 & 0.89 & 0.77 & 0.84 & 0.78 & 0.91 \\
\hline & 0 & 0 & 0 & 0 & 0 & -1 & 3 & 4 & $\begin{array}{l}5 \\
\end{array}$ & 5 & 5 \\
\hline \multirow[t]{2}{*}{ MQA } & 0.99 & 0.99 & 0.98 & 1.00 & 0.99 & 0.94 & 0.86 & 0.73 & 0.83 & 0.83 & 0.93 \\
\hline & 0 & 0 & 0 & 0 & 0 & -1 & 4 & 5 & 5 & 5 & 5 \\
\hline \multirow[t]{2}{*}{ CGO } & 0.99 & 0.99 & 0.99 & 0.99 & 1.00 & 0.94 & 0.87 & 0.74 & 0.82 & 0.83 & 0.93 \\
\hline & 0 & 0 & 0 & 0 & 0 & -1 & 4 & 5 & 5 & 5 & 5 \\
\hline \multirow[t]{2}{*}{ CFA } & 0.95 & 0.96 & 0.96 & 0.94 & 0.94 & 1.00 & 0.88 & 0.75 & 0.79 & 0.80 & 0.89 \\
\hline & 1 & 1 & 1 & 1 & 1 & 0 & 4 & 5 & 5 & 5 & 5 \\
\hline \multirow[t]{2}{*}{ CRI } & 0.88 & 0.88 & 0.89 & 0.86 & 0.87 & 0.88 & 1.00 & 0.73 & 0.70 & 0.77 & 0.81 \\
\hline & -3 & -3 & -3 & -4 & -4 & -4 & 0 & 1 & 1 & 1 & 1 \\
\hline \multirow[t]{2}{*}{ MLO } & 0.74 & 0.73 & 0.77 & 0.73 & 0.74 & 0.75 & 0.73 & 1.00 & 0.77 & 0.67 & 0.75 \\
\hline & -4 & -4 & -4 & -5 & -5 & -5 & -1 & 0 & 0 & 0 & 0 \\
\hline \multirow[t]{2}{*}{ ESP } & 0.79 & 0.80 & 0.84 & 0.83 & 0.82 & 0.79 & 0.70 & 0.77 & 1.00 & 0.83 & 0.83 \\
\hline & $\begin{array}{l}-5 \\
\end{array}$ & -5 & -5 & -5 & -5 & -5 & -1 & 0 & 0 & 0 & 0 \\
\hline \multirow[t]{2}{*}{ SIS } & 0.80 & 0.82 & 0.78 & 0.83 & 0.83 & 0.80 & 0.77 & 0.67 & 0.83 & 1.00 & 0.84 \\
\hline & -5 & -5 & -5 & -5 & -5 & -5 & -1 & 0 & 0 & 0 & 0 \\
\hline \multirow[t]{2}{*}{ ALT } & 0.92 & 0.91 & 0.91 & 0.93 & 0.93 & 0.89 & 0.81 & 0.75 & 0.83 & 0.84 & 1.00 \\
\hline & $\begin{array}{l}-5 \\
\end{array}$ & -5 & -5 & -5 & -5 & -5 & -1 & 0 & 0 & 0 & 0 \\
\hline
\end{tabular}

The $B-A$-series of all the stations have yearly cyclicality and the stable shape. This is especially incident for the series of stations of the Southern Hemisphere. They all are co-phased, except that for the tropical station CFA where 'methane events' begin 1 month earlier. The amplitudes are roughly equal.

The oscillations in $B-A$-series of all the stations are evidently seasonal, namely, minima are associated with the warm period of the year, while maxima with the cold period. This is illustrated by Fig. $5 a$, where the averages of elements of the $B-A$-series for each month of the calendar year are presented for stations ALT, CFA and SPO. In Fig. $5 b$ a backward cyclic shift by 5 months and a forward cyclic shift ${ }^{4}$ ) by 1 month are applied to the series of stations ALT (a polar station in the Northern Hemisphere) and CFA (a tropical station in the Southern hemisphere), respectively. The curves of the Southern Hemisphere stations, namely, of SPO and CFA, become very similar after the shifting. The curve for station ALT has practically the same yearly course, but a somewhat greater amplitude.

4) A cyclic time shift means a cyclic change of months. For example, the forward cyclic shift by 1 month is the follows: $1 \rightarrow 2,2 \rightarrow 3, \ldots, 11 \rightarrow 12,12 \rightarrow 1$ 

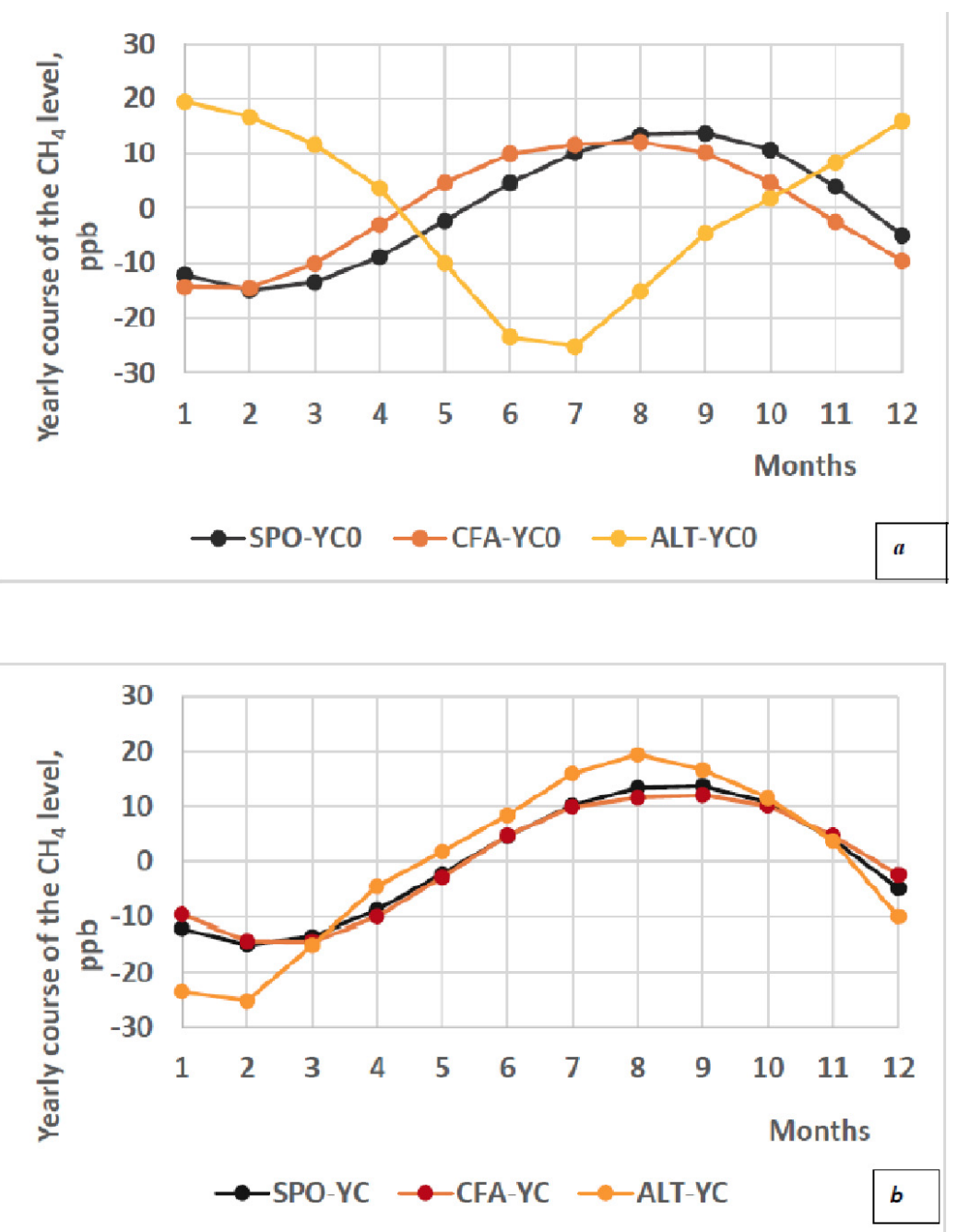

Figure 5. The results of the averaging of $B-A$-series by years for stations SPO, CFA and ALT: $a$ ) no time shifts are applied; $b$ ) the cyclic forward shift by 1 month and the cyclic backward shift by 5 months are applied for the series of station CFA and ALT, respectively. In the legend, YC0 is attached to the station code to denote the 'yearly course' with no time shifts, while YC is attached when those time shifts are applied

\section{Conclusions}

The series of present-day monthly data on the background concentrations of methane in the surface layer at 11 stations of the CSIRO network are analyzed. The network is of the global coverage: the highest-latitude station in the Northern Hemisphere is Alert $\left(82.5^{\circ} \mathrm{N}\right)$, while the most southern station in the Southern Hemisphere is the South Pole.

The data series are analyzed using two time scales, yearly and seasonal. For the analysis on the yearly time scale, first, a series of 12-month running averages $(A$ series) is constructed for each station. Further, systematic differences with such 
series for station Alert are eliminated from the series. It is found that long-term trends in methane levels are similar at all stations on this time scale. They are especially close for the stations of the Southern Hemisphere.

For the characterization of variability in $\mathrm{CH}_{4}$ concentration on the seasonal time scale, a series of bimestrial running averages ( $B$-series) is constructed and then the difference between this series and the series of 12-month running averages is calculated. The latter series is called ' $B-A$-series'.

Variations in methane concentrations on the seasonal time scale turned out to be similar at all the stations over the whole period of observations. Correlation coefficients are high, especially for the Southern Hemisphere stations. For those stations, the correlation with the series of station SPO is 0.95 and higher. However, to achieve such high correlations special time shifts are applied to compensate the seasonal differences.

Rise and decline in the methane level occur rather synchronically in each hemisphere as a whole, although small time shifts (by 1 month) are observed as approaching tropical latitudes. Time shift of 5 months characterizes differences between the polar and temperate zones of different hemispheres.

Variations in concentrations on the seasonal time scale have evident within-year cyclicality, the stable shape and seasonal dependence: deviations are positive in the cold season and negative in the warm season.

The stability of the oscillations' shape, their seasonality, implies that they are related to seasonal changes in the intensity of methane atmospheric sink. Since the oscillations considered are at the surface level, only seasonal variations in hydroxyl concentration can serve as a driver, because it is the major factor of methane sink in the lower atmosphere. Production of $\mathrm{OH}$ in the atmosphere is enhanced along with increase in the solar UV-radiation flux (Naik et al., 2013; Voulgarakis et al., 2013) that is season-dependent. The role of hydroxyl in methane variations are intensively studied now with model means.

\section{Acknowledgements}

The author is grateful to Paul Krummel and Ray Langenfelds (CSIRO, Australia) for providing information on existing web-resources that contain monitoring data on the background levels of greenhouse gases, and to Esther Ran'kova (Yu.A. Izrael Institute of Global Climate and Ecology, Moscow, Russia) for the verification of calculations.

\section{References}

Cicerone R.J., Oremland R.S. 1988. Biogeochemical aspects of atmospheric methane. - Glob. Biogeochem. Cycles, vol. 2, No. 4, pp. 299-327.

Collins M., Knutti R., Arblaster J., Dufresne J.-L., Fichefet T., Friedlingstein P., Gao X., Gutowski W.J., Johns T., Krinner G., Shongwe M., Tebaldi C., WeaverA. J., Wehner M. 2013. Long-term Climate Change: Projections, Commitments and 
Irreversibility. In: Climate Change 2013: The Physical Science Basis. Contribution of Working Group I to the Fifth Assessment Report of the Intergovernmental Panel on Climate Change [Stocker, T.F., D. Qin, G.-K. Plattner, M. Tignor, S.K. Allen, J. Boschung, A. Nauels, Y. Xia, V. Bex and P.M. Midgley (eds.)]. - Cambridge University Press, Cambridge, United Kingdom and New York, NY, USA.

Eliseev A.V. 2018. Global methane cycle: a review. - Fundamental and Applied Climatology, vol. 1, pp. 52 - 70. DOI: 10.21513/2410-8758-2018-1-52-70 (in Russian).

Francey R.J., Steele L.P., Spencer D.A., Langenfelds R.L., Law R.M., Krummel P.B., Fraser P.J., Etheridge D.M., Derek N., Coram S.A., Cooper L.N., Allison C.E., Porter L., Baly S. 2003. The CSIRO (Australia) measurement of greenhouse gases in the global atmosphere, report of the $11^{\text {th }}$ WMO/IAEA Meeting of Experts on Carbon Dioxide Concentration and Related Tracer Measurement Techniques, Tokyo, Japan, September 2001, S.Toru and S. Kazuto (editors), World Meteorological Organization Global Atmosphere Watch, pp. 97-111,

Karol I.L., Kiselev A.A. 2004. Atmospheric methane and global climate. Priroda, № 7, pp. 47-52 (in Russian)

Meinshausen M., Raper S., Wigley T. 2011. Emulating coupled atmosphereocean and carbon cycle models with a simpler model, MAGICC6. Part 1: Model description and calibration. - Atmos. Chem. Phys., No. 11, pp. 1417-1456.

Myhre G., Shindell D., Bréon F.-M., Collins W., Fuglestvedt J., Huang J., Koch D., Lamarque J.-F., Lee D., Mendoza B., Nakajima T., Robock A., Stephens G., Takemura T., Zhang H. 2013. Anthropogenic and Natural Radiative Forcing. In: Climate Change 2013: The Physical Science Basis. Contribution of Working Group I to the Fifth Assessment Report of the Intergovernmental Panel on Climate Change [Stocker, T.F., D. Qin, G.-K. Plattner, M. Tignor, S.K. Allen, J. Boschung, A. Nauels, Y. Xia, V. Bex and P.M. Midgley (eds.)]. - Cambridge University Press, Cambridge, United Kingdom and New York, NY, USA.

Naik V., Voulgarakis A., Fiore A.M., Horowitz L.W., Lamarque J.-F., M. Lin M., Prather M.J., Young P.J., D. Bergmann D., Cameron-Smith P.J., I. Cionni I., W. J. Collins W.J., Dalsøren S.B., Doherty R., Eyring V., Faluvegi G., Folberth G.A., Josse B.17, Lee Y.H., MacKenzie I.A., Nagashima T., van Noije T. P. C., Plummer D.A., Righi M., Rumbold S.T., Skeie R., Shindell D.T., Stevenson D.S., Strode S., Sudo K., Szopa S., Zeng G. 2013. Preindustrial to present-day changes in tropospheric hydroxyl radical and methane lifetime from the Atmospheric Chemistry and Climate Model Intercomparison Project (ACCMIP). - Atmos. Chem. Phys., No.13, pp. 5277-5298, www.atmos-chem-phys.net/13/5277/2013/ doi:10.5194/acp-13-5277-2013

Semenov S.M., Gelver E.S. 2002. Variations in the yearly course of daily mean air temperature over the Russian territory in the 20th century. - Doklady Earth Sciences, vol. 386, No. 7, 2002, pp. 846-850. Translated from Doklady Akademii Nauk, vol. 386, No. 3, pp. 389-394. 
Voulgarakis A., Naik V., Lamarque J.F., Shindell D.T., Young P., Prather M.J., Wild O., Field R., Sudo K., Szopa S., Zeng G. 2013. Analysis of present day and future $\mathrm{OH}$ and methane lifetime in the ACCMIP simulations. - Atmospheric Chemistry and Physics, vol. 13, pp. 2563-2587. doi: 10.5194/acp-13-2

Submitted : 08.06.2018.

Revised: 28.06.2018.

Referencing this paper:

Semenov S.M. 2018. Similarity of present-day variations in methane background concentrations in the surface layer of the atmosphere at different latitudes. Fundamental and Applied Climatology, vol. 3, pp. 124-137. DOI: 10.21513/2410-8758-2018-3-124-137.

Translation from Russian. The original is published in this volume, pp. 82-95. 